\author{
Andrzej Lisowski \\ University of Warsaw \\ Faculty of Geography and Regional Studies \\ Department of Urban Geography and Spatial Organization \\ email: alisowski@uw.edu.pl
}

\title{
GEOGRAPHY AND SOCIAL SCIENCES IN TRANSDISCIPLINARY SCIENCE
}

\begin{abstract}
The subject of the paper is the status and relationships of geography, especially human geography, with the social sciences on the background of the evolution of science from multidisciplinary to transdisciplinary. Progressive hybridization of disciplines and specialties upset the identity of geography in modern science, but geography (human geography), as she was, so it is hardly accepted as a social science among scientists. An important role is played by the traditional assignment of the entire geography to natural sciences and greater isolation of human geography in flows of knowledge within the social sciences. The article presents the specificities of the social sciences in the classification of the sciences, the impact of social sciences on past development of geography and contemporary impact of geography on spatial turn in the social sciences.
\end{abstract}

Key words: geography, human geography, social sciences, transdisciplinary science

\section{FROM MULTIDISCIPLINARY TO TRANSDISCIPLINARY SCIENCE}

In the history of science, processes of specialisation and differentiation have been accompanied by those of integration and unification. Their evaluation, however, has always been inconclusive. On the one hand, the ever-increasing number of scientific disciplines and specialisations reflects the striving for a more effective research work through a focus on clearly delineated spheres of reality, but on the other it has sometimes been undesirable owing to the growing distance between researchers as well as isolation and particularism of individual disciplines or specialisations. The belief in the unity of science has been reinforced every time when border disciplines have appeared or comprehensive and team-based research has been initiated.

Until the present day, the division of science into disciplines has been necessitated by the diversity of their subject matter and the effectiveness of 
research work. In the twentieth century, in addition to the epistemological conditions underpinning this division, the institutional conditions for a clearcut delineation of individual scientific disciplines became no less important. The borders thus determined provided the community of researchers with a sense of security. A given discipline ensured control over the research directions, university syllabuses, award of academic degrees, publications in a given discipline and allocation of funds. Pierre Bourdieu (1975) even saw a hidden relationship between domination and subordination in the very division of science into natural and social disciplines ${ }^{1}$. Until the mid-twentieth century, cognitive disciplines were viewed as superior to those associated with applied aspects. Arguably, the discussion on an unfair treatment of various disciplines of science is valid even today, when priority disciplines are expressly defined and leading academic institutions explicitly identified.

Nevertheless, excessive autonomy or even "isolationism" could prove unfavourable for the discipline at hand, protecting it against any external criticism of its research findings. Both openness and communication were rather constrained since the authors had a tendency to force their own ideas, terminologies, methods, philosophical or methodological underpinnings, which was even visible in the language used for the interpretation of the results. Social sciences saw such paradoxical situations where even the most eminent representatives of a given discipline were not familiar with their respective research findings or were uninterested in them. The sociologists Emil Durkheim and Max Weber could serve as an example in this regard. Durkheim, following the criticism of his work on suicide by Vilfredo Pareto, would avoid quoting any works written by his adversary (after Dogan, 1996). David Harvey (1969) complained that until the 1950s geographers would more often quote their own works than refer to the methodological works of other sciences ${ }^{2}$.

Regardless of such tendencies to defend the areas of research and autonomy of scientific disciplines, from the mid-nineteenth century onwards the process of the division of science was accompanied by efforts aimed at integration if not unification of scientific knowledge in epistemological terms (Kamiński, 1981). This process was considerably influenced by the positivism of Auguste Comte, evolutionism of Herbert Spencer and the nascent scientism of Charles Renouvier. The belief about the mutual influences and

\footnotetext{
${ }^{1}$ Natural sciences as "... the dominant class has no reason to expect anything from social sciences - beyond, at best, a particularly valuable contribution to the legitimating of the established order and a strengthening of the arsenal of symbolic instrument of domination (Bourdieu, 1975, 42).

${ }^{2}$ Unfortunately, this is not only a historical experience. World Development Report 2009 of the World Bank entitled Reshaping economic geography, scarcely cites the geographers. As the reviewers of the Report have written: "the absence of geographers work, and the almost total absence of geographers from the team that prepared the Report ...., reflects our discipline's failure to engage as much as the Report's failure to recognize." (Rigg et al., 2009, 130).
} 
interpenetration of different kinds of scientific knowledge referred to their philosophical and methodological underpinnings, indicating both the reductionist and hierarchical nature of the organisation of scientific knowledge (knowledge in science can be reduced to the level of the more basic science) and the universality of methodologies used in the natural sciences.

As a consequence of the division of science into disciplines, specialisations - or subdisciplines - gradually emerged within each scientific discipline. Specialisation with regard to the object of study was a safeguard of both methodological and theoretical development. In multidisciplinary science, internal fragmentation made it possible for researchers to explore in depth a given set of problems, by making their investigations more and more thorough. This, however, had a desired effect only in the short term. An analytical approach made it easier to identify problems but, with time, any given discipline had to make references to external factors influencing the analysed phenomenon or process, but also being investigated by another discipline or disciplines. In the twentieth century, fragmentation of science by seeking interrelationships between individual sciences led to the emergence of border sciences (two related sciences), and later to integrative sciences (Such and Szcześniak, 1999).

Initially, the border sciences were little but tolerated, and invariably occupied a lower place in the hierarchy than those specific disciplines which had a clearly defined object of research and well-established methodologies. This situation, however, changed dynamically as the internal fragmentation within individual disciplines progressed. During the last decades, the process of hybridisation of the science structure has gained momentum (Dogan and Pahre 1989; Dogan, 1996). It involves a flow of concepts, methods and theories from one specialisation (subdiscipline) of a given discipline to a specialisation of another discipline. As a rule, such hybrid subdisciplines do not occupy the space in between their "parent" disciplines; they can be entirely autonomous and aspire to be classified under the two disciplines involved (e.g. biogeography categorised as biology and as geography), or their classification is a result of the original education of their representatives or their current institutional affiliation.

The emergence of information society is associated with changes in how scientific knowledge is generated. The increasing role of external factors in the formulation of key research questions and in the selection of problem solutions can clearly be observed in the contemporary science (Such and Szcześniak, 1999). The scope of science is now defined by the economy, technology, social relations, intellectual trends to a much greater degree than ever before, alongside with empirical and theoretical cognitive considerations which played a dominant role in the past. The content of science is increasingly evaluated by the potential recipients of scientific works (by effectiveness, competitiveness and costs of solutions). New criteria of evaluation are accompanied by the dwindling role of recognised authorities in scientific institutions. The increasing costs of generating knowledge are 
responsible for a growing commercialisation of science. The decreasing usefulness of traditional organisational forms has led to an increased liquidity of the institutional structures of science. The staff numbers are growing so as the number of potential places where scientific knowledge can be generated. Such changes in the science give rise to concerns whether this externalism, which is now more easily observable in science, will not result in approving large numbers of works of inferior quality. Such concern is underpinned by the belief that external factors have an ambivalent influence on the development of science as they can both foster its development and its decline (Such and Szcześniak, 1999; Kaufmann and Kasztler, 2009).

The tendencies to "hybridise" science have been particularly reinforced by an increased interest in issues grounded in practice which less and less easily lend themselves to be clearly ascribed to the current structure of scientific disciplines. These disciplines no longer hold a monopoly on formulating the most interesting research problems. The uncertainty regarding the directions of contemporary change and the fallibility of scientific knowledge as we know it have, quite naturally, provided a premise for a transdisciplinary research focused on certain sections of reality (Gibbons et al., 1994). Transdisciplinarity is not a simple accumulation of knowledge from various disciplines; it hinges on specific issues, cooperation and a flexible organisation of the research process. As a rule, transdisciplinary scientific products make up an autonomous whole open to diverse modifications, subject to the application possibilities that exist in different contexts. The formulation of new methodological principles or theories does not have to lead to the emergence of a new scientific discipline.

To some extent, contemporary hybridisation processes in science bear resemblance to the organisational situation of science in the mid-nineteenth century, a time when the multitude of names proposed for individual disciplines was indeed overwhelming (Kamiński, 1981; Wallerstein et al., 1996). The structure of disciplines used since the mid-twentieth century is still in place, although it is questioned, and proposals of other structures are put forward. To take an example, 25 panels of the European Research Council comprise various fields of research classified under three research domains: social sciences and the humanities; natural and technical sciences, and life sciences. The barriers protecting the disciplines from outward access are becoming increasingly weaker ${ }^{3}$.

Proofs of the vitality of traditional disciplines are juxtaposed with the sweeping visions of change in the organisation of post-disciplinary science.

\footnotetext{
${ }^{3}$ It is best visible at scientific conferences and in journals, but can also be seen within scientific institutions themselves, such as the Faculty of Geography and Regional Studies at the University of Warsaw where 10 per cent of the staff hold degrees in other disciplines than geography. The author of the neo-positivist manifesto in geography - David Harvey - is currently a professor of anthropology at the City University of New York. Scientists are more and more frequently looking for recognition outside the academic structures, and consulting companies take part in the competition for grants against various university units.
} 
The new form of pursuing science has not as yet superseded the traditional one, and still is complementary in character. The very organisation of collaboration in science must inevitably rely on some categorisation of science. It is difficult to imagine that the scope of researchers' activities order in relatively stable institutional structures would be devoid of any order whatsoever. No career promotion in science is possible nowadays other than within a specific discipline. Although there is an observably growing convergence between individual disciplines in the theoretical dimension, but empirically, there still remains a diversity of perceived facts. In addition to that, every scientific discipline looks at the same phenomena in its own inimitable way, and has a different conceptual apparatus and methodology, embedded in the heritage of the discipline (Such, 1987).

\section{GEOGRAPHY AND CLASSIFICATIONS OF SCIENCE}

Contemporary geography is slightly awkwardly positioned in an era of post-disciplinary science, when the issues central to the very essence of geography (such as space, environment, region) have become issues of interest to many other scientific disciplines. The era of postmodernity has brought back the cyclical interpretation of history and an uncertainty as to where mankind is heading. The evolution of scientific structures from a relatively well arranged multidisciplinary structure into a transdisciplinary one has had unwelcome consequences for geography since the discipline has largely lost its identity as a result of this process. In analysing the contemporary situation of the discipline, one of British geographers even made a reference to the "fire of Rome" (Hamnett, 2003); in the same context, however, a colleague of his presented a dissimilar, and optimistic, vision of the future of geography (Thrift, 2002). However the contemporary social change and crisis phenomena have initiated debate about the crisis in many social sciences (Lopreato and Crippen 1999; Castree, 2005; Ratajczak, 2009).

Since time immemorial, informal geographical knowledge has been acquired out of curiosity about the environment. This knowledge shaped a relatively ordered and coherent view of the environment in the human minds. Such a reflection made the organisation of everyday life easier and ensured a sense of security. The geographical self-awareness associated with the microcosm of everyday life constitutes the very underpinnings of scientific geographical knowledge (Passen, 1957). Such informal geographical knowledge having a local dimension slowly began to be transformed into formal knowledge of a more universal nature, a process which took place via subsequent verifications taken down in writing, which ensured that such knowledge would now be useful for a greater number of people. The environment of a given subject could include the nearest surroundings of a given village or city or, just as well, a more spacious fragment of the earth's surface. Geography is a component of intellectual culture that has an exceptionally 


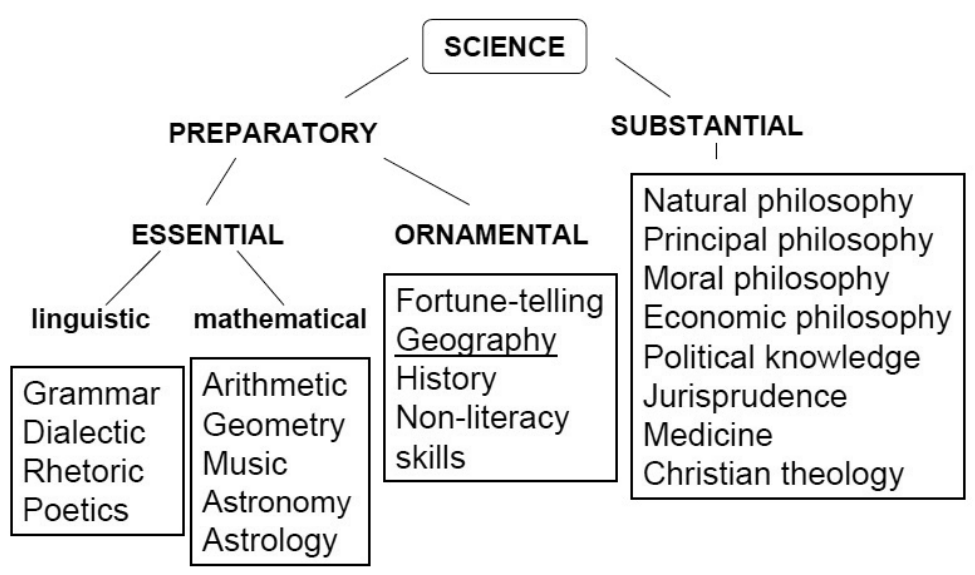

Fig. 1. Geography in the classification of sciences by Conrad Gesner 1545 Source: after Kotarbiński 1961, 453

long tradition and bears an ancient name (Geographika of Eratostenes; Geographike Hyphegesis of Ptolemy; Geographica hypomnemata of Strabo).

The classifications of sciences developed in antiquity do not list geography since the discipline was at the time a compendium of knowledge about the environment rather than a science. In it, verified information would go side by side with speculations. In the Middle Ages, the term "geography" was not circulated in the scientific context at all, and this situation lasted until the Renaissance, when it was restored by Johannes Schöner (1533). The Age of Discovery was bound to ensure that geography would make its presence in the scientific taxonomy of the time. Nevertheless, the role of geography in the classification of sciences proposed by Conrad Gesner in his monumental work, Bibliotheca Universalis published in 1545, was rather ambiguous (after Kotarbiński 1961, 433). Geography was not seen as an "substantial" but a "preparatory" science, and was not viewed as "essential" among the latter (as for example was astrology), but merely as an "ornamental" science, which group - in addition to geography - also included history and fortune telling (Fig. 1). This depreciation of the standing of geography and history was ascribed to the fact that those disciplines were not among mandatory university courses. They could be studied for "a more beautiful fashioning of the mind". The inclusion of history and geography into the same category as fortune telling could also stem from the fact that these disciplines were associated with "spin" - narratives that were either imagined or exaggerated (discovering the past or unearthing the present which is not too well known), intended to flatter the readers or serve the interests of those who sponsored the work in question. History wrestles for today with its taking scientific output for current propaganda and political requirements. 
From the very beginning, geography as a science has been a truly border discipline. Contemporary geography equally deals with issues which are the usual domain of the natural and social sciences, and with those from the realm of the humanities. It was claimed as early as the beginning of the twentieth century that geographers are free to choose what they want to explore, and geography is what geographers do (Brigham, 1915). While until the mid-twentieth century the nature and the economy were regarded as priority issues, at the end of the century increasingly political, social and cultural issues were studied by geographers to address their increasing significance as beheld by the general public. However, this extensive range of the subject matter of geography brought negative consequences in the form of the discipline's unclear status in the classification of sciences, a tendency for manifestation of an unjustified epistemological imperialism and a leaning for methodological eclecticism.

The question of the classification of geography in the scientific taxonomy was made much more complex by the increasing diversification within human geography itself. Until the Second World War anthropogeography, which emphasised the role of the natural environment in the human activities, was the dominant form of human geography in Poland. Starting from the midtwentieth century, this branch of geographic sciences was termed as economic geography owing to the ideological pre-eminence of the industrialisation process in the socialist economy, the social pressure on economic growth and spatial development of the country. A formal specialisation within economic geography was also introduced (1956). In the 1970s, economic geography was transformed into socio-economic geography, a format which has remained basically unchanged until today. In the late twentieth century, Polish geography did indeed become "socialised" and experienced a cultural turn, but this was done with the intensity that was no match for the scale of changes that characterised e.g. geography in the Anglo-Saxon countries. Nevertheless, these changes turned human geography into a social science to an unprecedented extent.

As a result, the endogenous explanation of the autonomous nature of geography as a discipline proved more and more problematic. The complex topical range of research and the attendant methodological problems made it difficult to promote a unified image of geography among other scientific disciplines. In the history of geographical thought, three major approaches to the development of the identity of geography as a separate discipline can be distinguished:

- the first involved attempts at defining the subject matter of the discipline through the elimination of certain categories of phenomena or processes or reduction of their significance and viewing them as ancillary;

- the second approach was a compromise which attempted to turn geography into a discipline which provides a synthesis of the knowledge of the Earth. Geography, not being a science with a specific nature of 
its object of research, has abandoned "hard" objects of study to embrace "soft" systems (Blaut, 1962, 5), and turned towards metaphysical objects, relationships and spaces, thus giving the discipline a topical identity and scientific credibility;

- the third approach referred to the "natural" diversity of the subject matter of geography, leading to a topical disintegration and its transformation into a set of geographic sciences (Maik, 2004) where the methods and the theory are derivative (Harvey, 1969), albeit to varying degrees.

The first approach was usually associated with a certain rivalry between the natural and social components of geography. The local traditions of the ties between geographers and geology or history, the current staff numbers and scientific achievements initially played a considerable role in this regard. The attempts to reduce the scope of study of the discipline either to a natural science or to a social science were the most radical way to lend it coherence. First, German physical geographers made an attempt to remove man from geography, in a protest against the tendency of the day to regard geography as an ancillary discipline of history. These views were manifested in the concept of "pure geography" developed in the late eighteenth and early nineteenth centuries, and the stance taken by the Georg Gerland towards the end of the nineteenth century (after Isačenko, 1975, 226). The proponents of "pure geography" recommended that political and economic issues, studies of the dependence of society on environment and even the measuring function (mathematical geography) should be excluded from geography. Gerland, a founder of the first journal explicitly naming geophysics in its title, believed that the study of economic and social issues by geographers was a breach of their scientific competences (after Isačenko 1975, 302).

Another attempt to reduce the scope of geography had been proposed in well-known article of Harlan Barrows $(1923,4)$ about geography as human ecology. According to the author, the subdisciplines of physical geography was so strongly linked with the related natural sciences that it was only study of relationships environment-society gave geography its separate identity in the system of sciences. The nature is only a background of human ecology. The structure of "new geography" should be determined by the forms of human activity (economic, political and social), whereas geographic physical subdisciplines should be included to natural sciences or to remain as independent sciences.

In the mid-twentieth century, in a period of the domination of economics as a reference science in human geography, the issue of the usefulness of physical geography in human geography came to the fore (Ackerman, 1963; Chojnicki, 1973; Brown, 1975). The pertinence of this issue was upheld by a dynamic development of social and cultural geography. The assumption that man is first and foremost a part of nature - which to a greater or lesser degree sets a barrier to development - in no uncertain terms categorised human geography as a natural science. The interactive relationship between 
nature and society as well as the ever-increasing conviction that nature has become a part of culture has shifted geography towards social sciences. Geography, in addition to Area Studies and Environmental Studies, is found in the list of social sciences of the International Social Science Council, whilst the issue of sustainable development is discussed within the field of social sciences at the panels organised by the European Research Council.

A compromise solution would be to award geography the status of a synthesising science, one that forms a link between nature and society. We can find the foundations for such an approach in the works of Immanuel Kant and Karl Ritter. Methodologically, such a synthesis involves an analysis of the relationships between nature and society seen against the context of spatial entities. The classical topical concepts of geography: regional, interactive (environment-society), landscape, chorological, are examples of such a synthesis. Originally, the idea of geography as a science integrating knowledge about the Earth was fraught with excessive inductionism ${ }^{4}$.

One advantage of the topical concepts of geography as spatial entities was the promotion of the discipline's topical separatism both in terms of substance and methodology. Holism in geography proved to be its strong point only superficially. Due to the complexity of the entities under research, this is a task that first and foremost calls for a good methodological background in integrative sciences (systems theory, cybernetics, synergetics). The share of the identification of spatial relationships was disproportionately high, at the expense of the functional relationships and structures; also a lot of emphasis was placed on form, at the expense of processes. Universal concepts of entities, espoused by geography in the previous century, viewed the role of spatial relationships, which played a cardinal role in geography, as secondary or complementary. This was the case with the notion of the system and, even more manifestly so, with the concept of networking ${ }^{5}$.

Finally, the third approach led to the division of geography and ascribing of a part of the discipline either to natural sciences or to social sciences. The idea of geography as a set of sciences appeared at the end of XIX century in Germany and Russia (after Isačenko, 1975). Hermann Wagner (1880, 524) considered geography as two separate complexes of sciences, physical and historical. Nevin M. Fenneman (1919) published a well-known multidisplinary structure of geography and its links to related disciplines. This trend was highly reinforced in the mid-twentieth century, in the course of the progressing specialisation of science. As a result, geography was divided into a set

${ }^{4}$ The eminent Polish geographer from the early twentieth century Ludomir Sawicki (1932, 3), firmly claimed that only an inductive geographical synthesis ensured “... a logical and consistent amalgamation into an organic whole of two perspectives: the humanistic and the natural".

5 This issue is reflected in the discussion on the scope of research of contemporary ecology. There is an ongoing dispute whether the traditional interrelationships, determining both the number and the distribution of organisms, should be the central object of research, or should it be the equilibrium and its disorders in ecological systems (thermodynamic and biogeochemical phenomena). 
of geographic sciences, a process which was intended to ensure that more spectacular scientific achievements will be made. At the end of the day, however, it induced the belief that there is no single geography, but many geographies (Lisowski, 1996). However, this topical disintegration had more far-reaching consequences. With time, such a stance came to assume that the methodological and theoretical output of other sciences will be made use of on an increased scale, a process which would lead to the domination of the derivative theory in geography (Harvey, 1969). This would qualify the discipline as a concrete (A. Comte), or systematic science (W. Wundt). Where physical objects and facts independent from the observer were studied, geographers tended to apply patterns of scientific cognition typical of the natural sciences, and where society played a substantial role - the naturalist cognitive patterns coexisted side by side with alternative approaches from the social sciences or the humanities.

\section{The rivalry between the natural and the social component in geography}

The rivalry between the natural and social component of geography in Poland has been associated with the attempts to separate the social component. The dominance of natural geography over human geography was firmly established at the turn of the twentieth century. At that time, most of the future professors at the departments of geography were awarded their first academic degrees abroad (Germany, Austria), primarily in geology (the beginnings of geography in the United States were similar). Human geography first emerged as a separate institutional entity in Poland in the early twentieth century, when two departments of geography were opened at the university of economics in Warsaw ${ }^{6}$.

As late as the 1930s, anthropogeography at universities was primarily viewed as a necessary addition to physical geography. Physical geographers in fact pursued anthropogeography, usually "expanding pure physical geography and occasionally injecting a number of cultural, anthropological and historical elements" (Melezin, 1985, 434). Bogdan Zaborski and Antoni Wrzosek (1939) emphasised that the topical structure of anthropogeography should be determined by the forms of human activity, and not by types of the environment, and that more attention should be placed on social factors. The spectacular symptom of the domination of the natural component in the inter-War geography was for example proposing the eminent geologist and

${ }^{6}$ Nowadays, departments of economic geography still operate at universities of economics, although some of them use different names (e.g. Department of Spatial and Environmental Economics at the Poznań University of Economics), whereas their staff acquire their degrees in economic sciences, and not geography. The first university department of economic geography was set up at the University of Poznań in 1924, and of anthropogeography - at the University of Warsaw in 1938. 
geographer, Mieczysław Limanowski, as a candidate for the position of the Head of the Chair of Anthropogeography at the University of Warsaw. The attempt to incorporate human geography and physical geography into separate faculties of the Jagiellonian University in 1945 met with a strong resistance from the geographic community. In 1948, the new Department of Anthropogeography was renamed the Department of Geography I and was relocated from the Faculty of the Humanities to the Faculty of Mathematics and Natural Sciences (Jackowski and Sołjan, 2009, 291-95). Stanisław Leszczycki, the leading figure of the Polish geography in the mid-twentieth century, did not risk to embark on a similar project within the structures of the Polish Academy of Sciences (PAN) in the 1950s.

After the Second World War, in the new political situation of Poland, and in line with the Marxist interpretation, the dissimilar character of the objects of research in physical and economic geography was underlined, as well as the existence of geographical sciences, but in practice geography was, institutionally, classified in its entirety as a natural science. The Earth sciences was the category of natural sciences where geography was most frequently found in the organisational structure of science in Poland. In the universities' departmental structures, geography still functions together with various natural sciences (such as geology, biology or oceanography). In 1952, within the structures of the Polish Academy of Sciences, the entire discipline was incorporated into Division III - Mathematical, Physical, Chemical, Geological and Geographical Sciences (geography placed in title of division), and later operated within a new Division VII - the Earth and Mining Sciences.

The classification of human geography (or strictly speaking economic geography) as a natural science five decades ago was associated with the domination of the naturalistic methodological paradigm. In the 1960s and 1970s, Polish human geography adopted the model of neopositivistic science. The subject matter included material objects on the earth's surface, predominantly products of human activity, whereas society tended to be objectified (labour, consumers). References to naturalism did not only enhance the status of economic geography in methodological terms, but also in a way served as a safeguard against excessive ideological indoctrination, unlike in other social sciences. As early as the 1950s, Polish economists would seek in geography a shelter against the socialist economy, while human geographers started to play a prominent role in spatial planning processes (including the Committee for Spatial Economy and Regional Planning of the Polish Academy of Sciences).

\section{Geography as an integrated discipline}

The idea of geography as a discipline consolidating knowledge about the surface of the Earth did not fall within the traditional criteria for diagnosing the internal autonomy of scientific disciplines. These criteria would nor- 
mally comprise a separate formal subject, the goal of research or research methods, whereas interdisciplinary approaches were underestimated until the mid-twentieth century. As early as the end of the nineteenth century "...geography appeared anachronistic in its generalist, synthesizing, nonanalytic penchants." (Wallerstein et al., 1996, 28-29).

Recognition of geography as a synthesizing science aroused interest in seeking a special place for geography in the set of sciences. However, irrespective of the declared focus of geography on synthesis, methodologist of science seldom accepted its topical identity. In the classification of sciences, geography was categorised as a separate discipline, with linkages to some of its topical concepts: chorological on the one hand and interactive on the other. In the former case, the ideas of time and space in the philosophy of Immanuel Kant proved particularly useful. Kant distinguished two basic ways for the categorisation of the object of research: logical and physical classification. The former refers to sets of objects which can be logically linked using certain similarities in the object language, regardless of where or when they occur. The latter distinguishes objects which occur in the same place or at the same time. History is a science that deals with the description and classification of objects in time, and geography - in space (James and Martin, 1981). In Poland, this idea was revisited by the philosopher Władysław Tatarkiewicz (1945), who juxtaposed typological, and not idiographic sciences with nomothetic sciences, and divided the typological sciences into historical (the temporal features of types are important), topographic (the spatial features of types are important) and systematic (both temporary and spatial features are left out of the picture). We can say therefore that he viewed geography as a topographic science.

In one of the classifications of sciences (Such, 1987), geography was counted among the biological sciences. In this classification, one can indirectly see the connection between the place of geography with one of the topical concepts of geography, i.e. the interactive concept: society - environment (geography as human ecology). This concept reduces the geography's scope of interest to two categories of the earth's space (which are, admittedly, very complex). Despite the complexity of its object of research, geography, unlike biophysics or biochemistry, has never been regarded as a border science. By a similar token, geography has not been included among the integrative sciences (systems theory, cybernetics, synergetics), although in the 1970s, Polish geography did assimilate a systemic approach to the analysed phenomena.

Geography quite seldom operates as an autonomous discipline within the science structures in Poland. At the Polish Academy of Arts and Sciences (PAU), geography forms a part of the Natural Sciences Division, whilst until the Second World War geographers organised in the PAU usually operated in the Physiographic Commission dominated by geologists, which itself was a part of the Division of Mathematics and Natural Sciences (Dybiec, 1993). The interdivisional Geographical Commission existed only for a short 
period, between 1926 and 1938. Nowadays, separate faculties of geography function only at the universities in Warsaw and Łódź. In the process of the recent reorganisation of the Divisions of the Polish Academy of Sciences (as of 2010) - the Earth Sciences were merged with the Exact Sciences, but the Academy's research unit (Institute of Geography and Spatial Management) was incorporated into the Division of Technical and Engineering Sciences. This is the first sign that formally geography has been accorded the status of an applied science in Poland .

\section{Separation of the social component in geography?}

In the discussion of the disintegration of geography in terms of its subject matter, institutional considerations are gaining in importance. The standing of the discipline in contemporary science is determined by organisational rather than substantive factors. Nigel Thrift (2002) pointed out the increasing hiatus between human geography and physical geography and saw a pressing need for developing a new institutionalised project for geography. The possible arrangements include: coexistence in the mode practised so far: "together but separately", separation or reintegration, but based on different principles than before.

The first Polish geographer who called for a division of geography in the system of sciences was Stanisław Nowakowski (1934-35). It can be found a little surprising, though, that a PhD student of Elsworth Huntington supported the view on the existence of many geographic sciences. In the 1930s, Nowakowski used a classification of sciences akin to the contemporary standards. In terms of the subject matter, he divided sciences into theoretical and applied. Theoretical sciences included natural and social sciences. He classified geography as a theoretical science, but one which belonged both to natural sciences (inorganic and organic geography) and social sciences (socio-geography, not human geography).

The place of geography in the classification of sciences is similarly interpreted by Stanisław Kamiński (1981). In this classification, geography is viewed as a disintegrated discipline which operates partly within the natural sciences (natural history), and partly within the humanities (economic sciences). It should be noted however that the authors of these classifications represented a social orientation in science (socio-geography or philosophy). Geography is also quoted as a disintegrated science in the classification proposed by Stanisław Krajewski (1982), who counted geography among the

\footnotetext{
${ }^{7}$ It should be borne in mind however that certain analogies can be found in European geography. For example, in the United Kingdom, Geography and Environmental Studies are found in panel $\mathrm{H}$ of the Research Assessment Exercise, which also includes Architecture and the Built Environment, Town and the Country Planning and Archaeology. A separate panel (E) comprises the Earth's Systems and Environmental Sciences, Physics and Chemistry (http:// www.rae.uk/pubs/2008).
} 


\begin{tabular}{|c|c|c|c|c|}
\hline \multicolumn{5}{|c|}{ Empirical Sciences } \\
\hline & \multicolumn{3}{|c|}{ Basic Sciences } & \multirow{3}{*}{ Applied Sciences } \\
\hline & \multirow[t]{2}{*}{ Nomothetic } & \multicolumn{2}{|c|}{ Idiographic-nomothetic } & \\
\hline & & Topographical & Historical & \\
\hline $\begin{array}{l}\text { Natural } \\
\text { Sciences }\end{array}$ & $\begin{array}{l}\text { Physics } \\
\text { Chemistry } \\
\text { Biology }\end{array}$ & $\begin{array}{l}\text { Astronomy (partly) } \\
\text { Physical geography } \\
\text { Biogeography }\end{array}$ & $\begin{array}{l}\text { Cosmogonia } \\
\text { Paleogeography } \\
\begin{array}{c}\text { Evolutionary } \\
\text { biology }\end{array}\end{array}$ & $\begin{array}{l}\text { Agricultural } \\
\text { Sciences } \\
\text { Medical Science }\end{array}$ \\
\hline $\begin{array}{l}\text { Social } \\
\text { Sciences }\end{array}$ & $\begin{array}{l}\text { Economics } \\
\text { Sociology } \\
\text { Political science }\end{array}$ & $\begin{array}{l}\text { Economic geography } \\
\text { Urban sociology } \\
\text { Social geography } \\
\text { Political geography }\end{array}$ & $\begin{array}{l}\text { Economic history } \\
\text { Historical } \\
\text { sociology } \\
\text { Political history }\end{array}$ & $\begin{array}{l}\text { Applied } \\
\text { Economics } \\
\text { Urban studies } \\
\text { Law }\end{array}$ \\
\hline
\end{tabular}

Fig. 2. Geographical sciences in the classification of science Source: Krajewski (1982, 230), modified

topographic sciences, in the group of nomothetic and idiographic sciences (Fig.2). He categorised the subfields of geography either as natural or as social sciences, and did not view geography as a unified science.

Heather Viles (2005) put forward two arguments in favour of a separate functioning of physical and human geography. Firstly, both these subfields of geography would be treated more seriously outside these disciplines if each had more and more stronger links with related research and researchers. Secondly, such a separation is inevitable due to the increasing differences in the theoretical and methodological foundations. In the former case, inclusion of geographers into the units of other disciplines could be seen as a solution. The only alternative seems to be the establishment of a new organisational structure of science as a whole, although Viles sees the same need if a reintegration of geography was to be attempted. A real paradox of history is the proposal to restructure the entire science by a representative of the discipline which until recently was perceived as the most interdisciplinary among the empirical sciences. Secondly, according to Viles, the increasing methodological differences between physical and human geography speak for their separation because the costs of research in physical geography and the infrastructural requirements considerably exceed the needs of human geography, and this leads to many tensions in the geographers' community.

On the other hand, Ron Johnston (2002) claims that the division of the small academic community of geographers seems risky because it may mean that the identity of geography will further be blurred. This temporary pres- 


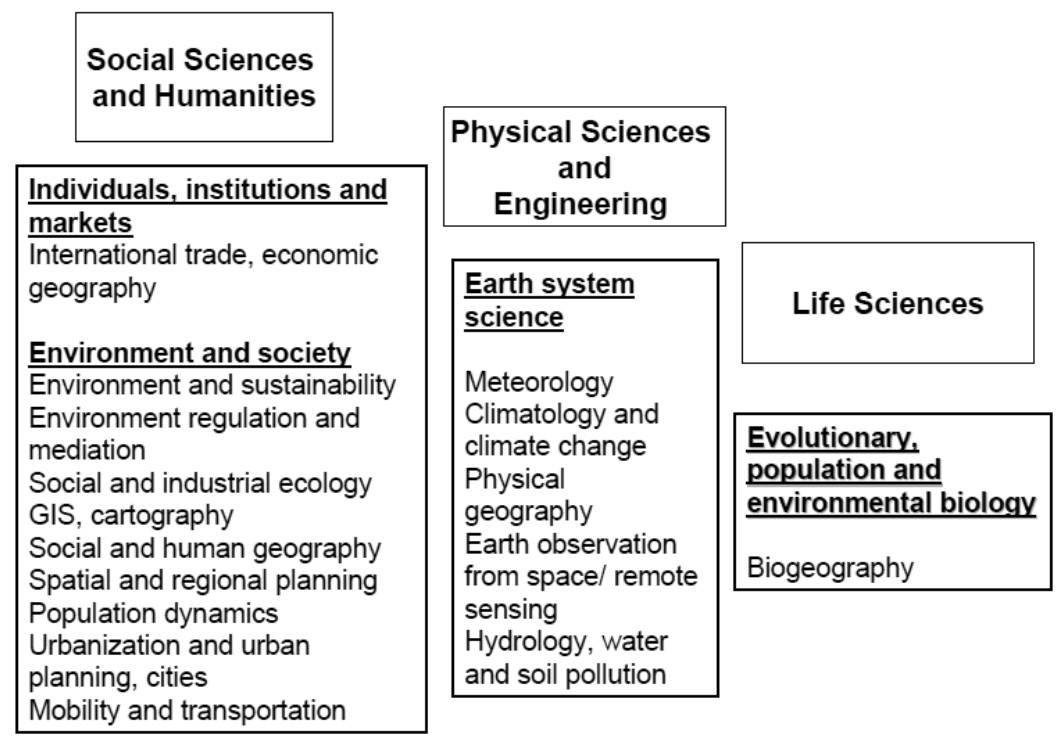

Fig. 3 Geographic descriptors in research domains of European Research Council Source: European Research Council 2008

sure on maintaining the status quo proves that there is a great deal of uncertainty concerning the future of geography. Any reintegration of geography seems rather unlikely because contemporary hybridisation of science takes place at the level of specialisations, and not such extensive and internally varied segments as human or physical geography. The relationships between society and nature are analysed either from the perspective of the natural sciences (man as an element of nature), or from the perspective of the social sciences (nature as a part of culture). However, there still exist certain possibilities for choice. Human geography may remain a poor testimony to the identity of a single geography; undergoing further marginalisation, it may be stronger integrated with social sciences (which was already the case of physical geography and natural sciences) or, ultimately, it may be transformed into an applied socio-spatial, integrated science. In the two latter cases, this means further crippling of the discipline's identity, but excessive cultivation of identity may, at the end of the day, also lead to marginalisation. Advancement of knowledge seems to be more important than the stubborn preservation of disciplinary tradition.

Decisions on the future of geography may be made outside geography. The ongoing reform of the financial aspects of science in Poland is modelled on the experiences of the European Research Council related to the structuring of the fields and scientific issues on the basis of its Panel Structure and Descriptors (Fig. 3.). The proposal of panels at the National Science Centre $(\mathrm{NCN})$ which will award research funds as part of research project competi- 
tions is not advantageous for geography, and for human geography in particular. Although 25 such panels have been set up, unlike the original European classification their structure has been changed. In the field Humanities and Social Sciences, the panel Environment and society, which covered most issues related to human geography having transdisciplinary values, has been disbanded. Only several descriptors have been moved to the panel Individuals, institutions and markets. A separate panel was established for legal and political sciences (Norms and power). In addition to that, many new descriptors have been introduced in social sciences; these descriptors do not draw on the research issues but on the existing structure of subdisciplines in the social sciences, which stands in contradiction to the concept of transdisciplinary science ${ }^{8}$.

\section{SOCIAL SCIENCES}

Social sciences are categorised in the group of empirical sciences. They are noted for considerable differences in the philosophical and methodological approaches to the examined social phenomena. The axiological dimension plays a major part in social sciences. In their narrow meaning, social sciences are understood as sciences about the human societies, whilst the humanities are sciences about human beings as individuals, which look at the cultural and intellectual products of human societies. In addition to that, the division into social sciences and the humanities is not only based on the subject matter but also on methodological considerations since social sciences are perceived as nomothetic, whereas the humanities - as idiographic. In fact, a split for nomothetic and idiographic sciences is a simple typology, because the defined classes are not disjoint. Typology of science may be based also on the dominant type of explanation. From this point of conduction Adam Grobler (2006, 251) distinguishes deductive science (formal proof), natural (causal explanation), life sciences (causal explanation and functional), social sciences (functional explanation and intentional) and the science of behaviour (causal explanation and intentional).

Although in the nineteenth century August Comte counted sociology, and Wilhelm Wundt, psychology, among the law-forming sciences, these disciplines did not have their university departments until the end of the nineteenth and the beginning of the twentieth century, unlike economics, history or geography. The latter began to be taught at universities at least a hundred years earlier, owing not so much to their theoretical achievements as to the greater practicality of knowledge, including factual knowledge. The

\footnotetext{
${ }^{8}$ Otherwise, in the field of Physical and Engineering Sciences, the panel of Earth Sciences has remained. It takes into account the main descriptors associated with the physical geography (geoecology, protection of the natural environment, climatology, hydrology, physical geography and geomorphology, soil science, remote sensing).
} 
role of history and geography in the emergence of national states in Europe can hardly be overestimated. In Poland, a true visionary in this regard was the poet Wincenty Pol (founder of the department of geography at the Jagiellonian University in 1849). In Germany, even a regulation recommending the establishment of departments of geography at state universities was proclaimed (1874). Leaving aside the period of the politicians' fascination in political geography and geopolitics in the first half of the twentieth century, another period of a marked appreciation of the European public for geography came in the 1950s and 1960s, which was the pinnacle period of the "welfare state". At that time, state institutions would manifest extensive interest in diagnostic and experts' studies needed for regional planning purposes, and geographers proved more competitive in that respect than representatives of other disciplines (Jahn, 1990).

In both their wider and narrower meaning, social sciences represent quite a numerous group of disciplines. The classification of the fields of science proposed by OECD in 2004 distinguishes between the social sciences (e.g. economics and management, sociology, political studies, psychology, law, pedagogy, media and communications, social and economic geography) and the humanities (history, archaeology, linguistics and literary studies, philosophy, ethics, religious studies).

The proposal of the Gulbenkian Commission on the Restructuring of the Social Sciences (Wallerstein et al., 1996) seemed quite controversial as it included the following disciplines into the realm of social sciences: history, economics, sociology, political science, (cultural) anthropology and Oriental studies. According to the Commission, economics, sociology and political science form the core of the social sciences since they deal with the economy, society and the state. Such disciplines as geography, psychology and law were not considered among social sciences owing to a number of reasons, although they are included in the social sciences by other classifications. Both psychology and geography were believed to have too strong links with the natural sciences and the humanities, and law was thought to be too normative in character and too little grounded in empirical research. Cultural anthropology and Oriental studies - unlike geography - had a much more clearly defined object of research. At the same time, any attribution of the weaknesses of nomothetic approaches to geography stands in sharp contrast with the inclusion of history into the social sciences on the grounds that it refutes speculative philosophy and puts an emphasis on the rigorous search for the truth.

Generally speaking, all the social sciences are characterised by a considerable degree of heterogeneity in terms of their subject matter, which is proved by the difficulties with universally accepted definitions of study areas. It might seem that their diversity ties these disciplines more closely with the entire stock of knowledge and helps find "a common language" for research conducted jointly with other disciplines, which would be of considerable importance in an era of the hybridisation of science. However, a bibliometric analysis of the links of social sciences with other groups of disciplines shows 
that their external ties among nine groups of scientific disciplines are rather poor (Morrillo et al., 2003). Among the social sciences, anthropology is ranked first in terms of the assimilation of knowledge from other groups of sciences, followed by geography, and then psychology, all of them having the strongest links with the natural sciences (Laponce, 1980). Nevertheless, the gap between human geography and social sciences seems stronger than the one between physical geography and natural sciences because human geographers from Anglo-Saxon countries publish their works in geographic journals more frequently than physical geographers, who in turn publish more often in the journals of other natural sciences (Johnston, 2002).

In light of the classification of the discipline-based structures (Dominiak, 2006), social sciences could be termed a "constellation", with unexplored fields of research and a convenient situation for establishing cooperation, rather than a "solar system" where hierarchical interdependencies can be observed. Economics and psychology are the disciplines which provide the bulk of knowledge in the social sciences, followed by sociology and political science. At the same time, sociology, political science and anthropology are major importers of the output of other social sciences.

In the comparisons drawn by Jean Laponce (1980), geography and history were the most "autarchic" in the flow of knowledge within the social sciences, although the fragmentary nature of this bibliometric analysis suggests caution in drawing any far-fetched conclusions. The bibliometric analysis carried out in the United Kingdom (Research Assessment Exercise 2001) revealed that representatives of human geography were more open than representatives of sociology and political science since they would publish their works in both international and interdisciplinary journals (Johnston, 2003). Economics was just as open, although economists would more frequently publish in economic journals than in interdisciplinary ones. However, a closer look at publications in the field of social sciences suggests that the balance of quotations is not favourable for geographers. A spectacular example of recent years is the World Developement Report 2009 of World Bank. Despite dealing with the similar research issues, the literature quoted by representatives of the social sciences only infrequently lists geographical works, contrary to geographers who very diligently try to make references both to the classic and new publications in a given subject area (Johnston, 2003, 139; Lisowski, 2004, 74).

Geography and history also had similar problems with being perceived as sciences in the twentieth century as they had in the times of Conrad Gesner. A spectacular development in this respect was the liquidation of the department of geography at Harvard University in 1948 (Smith, 1987), a move which was caused by a whole set of factors (substantive, personal and financial). It led to the elimination of geography from the Department of Geology and Geography, the two disciplines which in the early twentieth century were often part of the same academic units at U.S. universities. Geography did not return to Harvard until 2006, this time as the Center for 
Geographical Analysis, which supports various projects using new spatial analyses techniques (its director is a professor of East Asian languages). On the other hand, history was not accorded the status of a nomothetic science, in the prestigious UNESCO publication Main Trends of Research in the Social and Human Sciences (Volume 1) in 1970 (after Dogan, 1996).

Owing to the degree of generality and reliability of their tenets and propositions, social sciences more frequently develop generalisations rather than theories which are verifiable in a large number of cases. The disciplines which are closest to this orientation due to a greater degree of formalisation and mathematisation are economics and psychology. Additionally, economics has been the science which put forward the greatest number of theories having a broader range, which in effect led to a "colonisation" of many social sciences (Brzeziński et al., 2008). Economics is the only discipline among the social sciences in which the Nobel Memorial Prize is awarded. According to the Thomson Reuters Social Sciences Citation Index (World Social Science Report 2010, 194-5), most of the publications from the period 1980-2007 were in the field of psychology and economics, and Jon Elster (2010) believes that microeconomics (behavioural economics) and social psychology will be privileged fields of the social sciences in the nearest future.

\section{SOCIAL SCIENCES IN GEOGRAPHY}

The relationship between geography (human geography) and all the social sciences would merit a much more extensive discussion. Our considerations are general in nature, intended to summarise the consequences of such interrelationships for geography itself, and are mainly related to its ties with history, economics, psychology and sociology. Although the benefits from mutual borrowings are quite obvious, selective absorption has usually been an unwelcome side product of methodological and theoretical borrowings as it led to excessive simplifications, at least in the opinion of the representatives of the disciplines which in this way exported their achievements.

The problem of geography is not only associated with its subject matter, which lacks clear-cut boundaries, but also with the impossibility to solve one of the crucial philosophical and methodological issues - the relationship between universalism and diversity (Burt, 2005). This issue should be analysed in terms of the research field of a given discipline and the methodological approaches. The history of geographical thought reflects the constant struggle between making geographical knowledge more universal in character, and the cult of specific facts underlining the variety and peculiarities of the components of earth's surface.

\footnotetext{
${ }^{9}$ At this point it is worthwhile mentioning the results of the survey carried out in the USA in 2006. That survey showed that over $90 \%$ of respondents assigned a status of a very or pretty scientific discipline to physics, biology and medicine, while $51 \%$ to economics, $49 \%$ to sociology and only $31 \%$ to history (http://asociologist.word.press.com).
} 
Initially, human geography tried to deal with this problem in two ways. Even in the nineteenth century geography was thought to be an ancillary science of history, which provided the natural science context for exploring the history of society. Relationships with history proved quite lasting; this is manifested by the introduction of Heinrich Rickert's individualising method (factual historicism) into geography, which accorded human geography with a status of idiographic science, focusing on its unique, inimitable attributes of specific areas (regions).

On the other hand, universalism was inculcated by the study of the impact of the natural conditions on social development, even though geography would typically use the phrase "life and activity of man". These issues were often tackled earlier, or concurrently, by various social sciences. An entire trend emerged in the so-called evolutionist sociology in the mid-nineteenth century, which investigated factors underlying social change in the external conditions, predominantly those associated with the natural life (F. Le Play, H.T. Buckle, A. Bastian). Both these trends espoused the view of geography as a science synthesizing knowledge about the Earth, viewed from the perspective of human life and activity.

Since its very beginning, the frequently intuitive grasp of the interrelationships between the apparently unrelated phenomena has been the domain of geography. Identification of the natural spatial order of individual territories through the studies of spatial diversities has been the method to perceive reality in a way that facilitates its understanding (Hartshorne, 1959). In the past, the approach to reality shared by history and geography was to seek interrelationships between facts based on their concurrence in time or in space (actio directa). Such identification of concurring facts would often make the causal relationships more reliable, in the absence of other explanatory arguments. The tasks set for geography in this way were fraught with the risk that geography would be transformed into geosophy. The difference between historiosophy or geosophy and empirical science is that the former attempt to offer comprehensive interpretations which are highly generalised and communicative, at the expense of methodological rigour that is typical of empirical and analytical science. Just as the meaning of history, that is, notions and principles which can make the historical process is understandable - and assessable - not only for historians but also for the public at large, the meaning of spatial diversities was to become comprehensible for every recipient of geographical knowledge (Lisowski, 2003).

The allegations, made since the mid-twentieth century, that the research of spatial structures is unduly static and the resultant model explanations are unreliable, have brought back the significance of history as a model science (history matters) for human geography, in the form that largely drew on idiographic historicism. The concept of path-dependency (David, 2003) places considerable emphasis on exceptional phenomena, arbitrary decisions, randomness and unpredictability of decisions related to the location or actual progress of development process. 
On the other hand, environmental determinism, which has been dubbed geographical determinism due to its longest ties with geography, was a model approach to research in the methodological sense as a kind of mainstream (defined set of relationships). However, in empirical studies the explanatory sketches were contained rather than explanation of relationships. In some cases, the dubious line of argumentation was a consequence of applying simple research methods. The debate on the nature of the relationships and research techniques was rather tepid. Comparative studies of different areas were popular and the proponents of environmental studies were not fully convinced of the shortcomings of their empirical argumentation. However the special role of the environmental factors validated the view of geography as a separate field of study.

In other social sciences, the environmental approach was initially of a marginal significance (social ecology, cultural anthropology), which originated from a growing conviction that societies are not as susceptible to biological and physical conditions. Contemporarily, the lesser interest in the structure and material foundations of social relations plays down the role of the "environment" (even as a social environment), but on the other hand environmental issues find their way into the border disciplines of the social sciences in economics (economic ecology, environmental economics), sociology (environmental sociology) and psychology (environmental psychology, psychology of sustainability) and in new integrative sciences (environmental science, sustainability science). As a rule, in presenting their history, they tend to omit even traces of their linkages with human geography, to underline their own originality as a science.

There can be little doubt that economics was the science which brought geography the closest to the paradigm of an empirical and analytical science at the mid-twentieth century. In traditional societies which are relatively isolated, the emphasis was placed on the local factors and limitations to development, which were mostly related to the natural world. Due to the increasing socio-economic openness of the society as a result of rapid industrialisation and urbanisation, the growing division of labour, specialisation and social and spatial cooperation, mutual dependencies would increase between business entities operating in various locations. The economisation of human geography was not only associated with its focus on economic issues but also with a methodological revolution. It was believed that the concept of the relative space and the temporal-spatial language will ensure that novel geographical theories will be developed, in line with the neopositivistic science paradigm and the inevitable mathematisation of the research methods. The concept of relative space has shifted the geographers' interest to the studying of interdependencies within certain spatial entities: the functions of individual components within such entities and their mutual interactions.

As compared with the period of historicism and determinism, priority was given to the functional and systemic explanation of phenomena, at the expense of genetic and causal argumentation. In geography as a spatial science, 
the introduction of the concept of spatial structure (pattern, system) was a momentous step. The notions of the form and structure and identification of lasting and universal components were viewed as tools to combat historicism in human geography, owing to its sole focus on what is unique and unrepeatable. Spatial organisation became the object of study, understood as an order relating to the location and distribution of components (functional regions, spatial systems) and the development of structures through self-regulation and regulation processes (Chojnicki, 1996).

The identification of spatial organisation referred to the "mechanisms" which were inherent in the very structures as the potential of components and the distances between them, and to the "mechanisms" resulting from the principles of the rationality of the homo oeconomicus, in keeping with the tenets of the neoclassical economics. Universal behaviours of the objectified "human masses" were to be determined by: the principle of least effort, the costs of transport, and the utility maximisation of locations.

It has to be borne in mind, however, that the evaluation of the aforementioned experiences is not at all unambiguous. The constructed spatial structure models were normative in character and played a heuristic rather than explanatory role. Only too frequently would they merely expound the disparities between the model and the reality, indicating that the conditions for which the model had been devised were not fulfilled. Spatial structure models could not perform the function of a scientific theory because they lacked clearly defined empirical tests. The critical attitude to the "new economic geography" (new trade theory) can serve as proof of the persisting reserve vis-à-vis the neo-positivist approaches (Martin, 1999). The geographers define "new economic geography" as geographical economics, whereas geographic new economic geography is not merely concerned with the economic realm, but it contextetualizes economic processes by situating them within different social, political and cultural relations (Coe et al., 2007; Aoyama et al., 2011).

However, the growing demand for applied research observable at the turn of the century increased the interest of the geographers in management issues (natural and human resources management, spatial management) and the business location theory.

Just as in the past determinism did not satisfy the geographers' demand, so economisation of geography began to lose momentum in the late 1970s, a time of the social turn in human geography. The geographers' attention shifted to social phenomena and processes. The colonisation of geography by economics was already accompanied by an expansion of behavioural and environmental psychology. In the mid-twentieth century, the built environment considerably increased. That end-product of large number of individual decisions brought both positive and negative effects. Changes in the forms and functions in space could not be explained without drawing on the images of the perceived space (cognitive maps), viewed as sets of information and values (evaluative maps). It was expected that the knowledge about 
cognitive maps would provide a basis for more efficient actions. Human behaviours intended to satisfy the needs were necessitated by the volume and quality of information about space and the abilities of individuals to make use of such information (Golledge and Stimson, 1997).

Within geography itself, the output of perception and behavioural studies is viewed rather critically (Johnston, 1995; Kitchen and Blades, 2002). The issue of the relationships between objective and subjective space (and deformations of the former), of great interest to geographers, resembled seeking deviations from the constructed spatial structure models. Information as such is not the only factor that influences behaviours (other such factors include social structure, values, minimisation of risk, intuition). Some doubts appeared concerning the reliability of the measurements of the representations of space in the human awareness and of the relationships between representations of space and behaviours.

The psychologisation of geography preceded the sociologisation of geography in the wake of the assumption that the spatial order of a given territory is generated by the society and also affects the social structure (the concept of social space). In social space, the relationships between human beings and physical space are interactive in character. Physical space is embedded in social relations by the provision of forms, functions and meanings, whereas the spatial order acts as a mediator in social relations, social communication and identity formation (Castells, 1977; Lefebvre, 1991). The social principles and norms, economic, political, cultural structures, but also the human body, gender, ethnicity, determine the forms, functions and meanings of the space of various places: locality, neighbourhood, social institutions (school, prison, workplace) and city streets. This process reciprocally sustains the reproduction of the existing social structures and development of self-identity (Valentine, 2000; del Casino, 2009).

The clear shift of human geography from spatial structures towards development processes, visible at the turn of the century, made space a frame of reference for the studying of such issues, which in turn brought geography closer to the sociology and cultural anthropology. Greater competitiveness and creativity in economic activity was also sought in a broad spectrum of social and cultural factors: institutions, social networks, human and social capital, cultural assets (Aoyoma et. al., 2011). The social relations locally became important. The reterritorialisation accompanying globalisation processes began to cripple the existing forms of socio-spatial organisation which had been shaped in the industrial society. The reterritorialisation of the world shifted the emphasis to smaller territorial units, which were more susceptible to change. Increased interest in the local areas was also the result of the increasing decentralisation and deregulation nationally, when the sense of community and belonging to a given area was regarded as a significant factor of social mobilisation (Lisowski, 2009).

At the turn of the century, the increased attractiveness of cultural analyses, postmodernism, semiotics, reduced the interest in the traditional field of 
socio-economic geography, where the spatial structure played an important role. The relativisation of space to subject underscores the issues of developing individual identities and fulfilment of individual projects and plans (Bridge and Watson, 2000). Human contact with space is treated as a source of momentary excitement intended to satisfy fleeting curiosity and provide entertainment; it is supposed to offer opportunities for fulfilling one's dreams about keeping up with the changes taking place in the contemporary world (cosmopolitanism, multiculturalism) or to reinforce the personal belief in the ever-lasting values of the past (tradition and memories), to suit individual needs.

The increased role of social and cultural issues introduced the paradigm of hermeneutical and critical science into human geography (Castree, 2005). The latter is especially controversial as it performs an emancipatory function, sometimes coming dangerously close to specific ideological options and stressing the geography's status as a consumer, and not a producer of knowledge (Mulligan, 2003), and even undermines the status of geography as a science (Castree, 2005). It is the task of the researchers to make the recipients aware of the principles of social organisation, with a view to initiating dissent behaviours aimed to modify or change the prevailing social rules.

\section{GEOGRAPHY IN SOCIAL SCIENCES}

For geography, its relationships with other disciplines matter enormously because it is a field of science which has always had problems with finding a place for itself in the classification of sciences. According to Robert Kates (2002), nowadays there are no safe disciplines on the map of contemporary knowledge, and B.L. Turner II (2002) claims that the direst danger for geography is posed not by traditional disciplines but by the newly emerging integrative sciences. Regretfully, instilling fear is among the key measures used to maintaining the acceptance of status quo in information society (Hardt and Negri 2000). Towards the end of the twentieth century, the situation of geography in the system of sciences began to resemble that of a social community which had lived in isolation before, convinced about its traditional separateness, but which succumbed to the ever-increasing influence of some kind of globalisation processes. Fortunately, geographers stopped cultivating autarchy in relations with other social disciplines in the mid-twentieth century, and this certainly facilitated methodological progress. The sense of loss of the traditional identity is probably not more acute than in other disciplines of this group of sciences. In the past, interdisciplinary as well as spatial approaches were mostly ascribed to geography, due to their limited use in other disciplines. The rapid expansion of spatial studies in the social sciences has unclear consequences for geography and resembles discussions on the positive and negative social consequences of globalisation processes ${ }^{10}$.

${ }^{10}$ At this point, let us recall the opinion of Polish historian Marcin Kula (2010), who expressed 
The impact of the social sciences on the formulation of issues and their solution in the field of geography cannot be overestimated. What is the contribution of geography itself to the social sciences? Among the new fields of research in the social sciences, the World Social Science Report 2010 (pp. 203-218) lists e.g. spatial analysis (spatial turn), environmental and ecological economics and psychology of sustainability. Although the contribution of geography is clearly emphasised in the former case, including the discipline's new research methods (GIS), the output of geography in other fields of the social sciences has not been fully recognised. Unfortunately, the report does not provide the updated bibliometric analysis of the flow of knowledge within social sciences, focusing on international comparisons instead ${ }^{11}$.

The process of absorption of the spatial approach in the social sciences gained momentum over fifty years ago. In the 1940s and 1950s, the decolonisation processes triggered the emergence of the field of research known as Area Studies. The interdisciplinary social research focused its attention on territorial communities which had recently gained political sovereignty and pursued the path of modernisation. Some time later Regional Science emerged (1956), in which economisation and mathematisation were at a more advanced level than in human geography; later a variety of local and regional studies appeared. Those hybrids were established on the initiative of economists, political scientists, sociologists, cultural anthropologists, and with or without geographers. In some cases, the definitions of the tasks set for those disciplines overlap with the field of geography's interest. Representatives of these new fields of study may at times be utterly unfamiliar with the output of geography, and their "innovative hypotheses" will only give the geographer a sense of déjà vu (Kuijper, 2008). In those new disciplines, geography is usually considered as an ancillary science, whereas the geographical component is frequently treated on a par with the natural one.

In the information society, the interest in spatial issues in social sciences is undoubtedly a consequence of decentralisation, deregulation and individualisation of social life on the one hand, and one the other can it be viewed as a defensive reaction of many regional and local communities to protect them against being overwhelmed by the accelerating processes of social homogenisation and heterogenisation caused by globalisation. During the last century, the earth's surface has become a scarce commodity, a fact which only stirred up in the interest in the principles of spatial order as well as the principles of sustainable development. Globalisation processes led a to new diversification of the world (reterritorialisation) and increased the societal awareness of the world's diversity. The uncertainty concerning the

\footnotetext{
his regret about to the limited openness of history to other social sciences and the present day (sic!), as this did indeed help maintain the identity of the discipline but also consolidated the perception of historians as those who are specialised in putting old papers in order, and nowadays makes it difficult for history graduates to find employment.

${ }^{11}$ Polish was the ninth prevalent world language in social science journals in 2004, according to Ulrich's classification.
} 
directions of contemporary change and the fallibility of scientific knowledge have naturally created conditions which favour transdisciplinary studies in which the spatial approach plays a major part. Such an approach makes it possible to depart from meta-narration towards a greater contextualisation of issues.

Human geography has undoubtedly helped sustain the interest of the social sciences in territorial communities since the temporal conceptualisation of social life, forced by the treatment of time as a central economic asset, led to the marginalisation of spatial awareness and spatial diversity of the social world in the industrial society (Soja, 1989). Such a deprecation of space however must have been underpinned by some methodological premises. The temporal approach to social issues still seems to prevail over the spatial approach because time is not expressed in such an abundant number of relevant formal structures as is space (Chojnicki, 1988).

Initially, spatial studies in other social sciences had a predominantly cognitive function; they served as tools for arranging information about the world or as instruments used in the search of interdisciplinary theoretical and methodological approaches. Contemporarily, the presence of spatial studies in many disciplines has been necessitated by public procurement procedures as well as expectations of an increased share of the applied science factor in the research findings. As a result, we can observe a rapid increase in the number of newly-founded academic units in the sphere of social sciences which define their field of study on the basis of the area, and not the thematic scope. There is an increasing conviction in the social sciences that regional knowledge is predominantly the domain of applied sciences since it is used in the decision-making processes in the sphere of social, economic and ecological policies (Chojnicki, 2004). According to the area-based approach (Andersson and Musterd, 2003), it is believed that allocation of relevant aid or development funds to a specific problem area is more effective than the sector-based distribution of such funds.

All this said, it has to be noted that the attitude to space remains ambiguous in the social sciences. According to Immanuel Wallerstein (1996), geography was not regarded as a social science precisely because spatial aspects tend to be underestimated in these disciplines. Under assumption of universality of social processes the space became only a background or a scene of events. When the processes were unique then the space became only the second hand factor, but not substantial issue. At present, the "end of geography" is heralded due to the diminishing role of distance and deterritorialisation in the social organisation on the one hand, and on the other there is a growing interest in territorial communities driven by theoretical considerations since the society in the era of globalisation is a dynamic structure characterised by the increasing role of external relationships. In Poland, the first study on the sociology of space was published in the 1970s (Wallis, 1971; Kaltenberg-Kwiatkowska, 2004), but a well-known sociology textbook in Polish (Sztompka, 2002), written by the former president of the 
International Sociological Association, had a separate chapter of time, and none such - about space.

Some of the works published in the 1990s which drew on the tenets of post-structuralism, seem to manifest scepticism as to the possibilities of using the concept of space in social science (Giddens, 1991). According to Benno Werlen $(1993,3)$, space just as time is a way to express the relationships between objects and phenomena, but only in the material world. Space is no longer a determinant, and least so a reflection, of the social relations, and provides only a frame of reference in the physical world, and a method for organising observations and experiences. Those sociologists who look at physical space as an intermediary body in social relations are even dubbed spatial determinists. It could be the reason why, contemporarily, more representatives of other social sciences than sociologists themselves deal with social problems in the cities (after Dogan, 1996).

In the past, physical space was a determinant of human behaviours. In the actor-network theory, physical space in fact loses its autonomy, because in the network - which replaces the notion of both space and structure emphasis is placed on the dynamic linkages between subjects (actants), be they objects, individuals, social groups or institutions (Bingham and Thrift, 2000). Geographers are probably more competitive in analysing processes of interactions at different spatial scales (local, regional, global), but contemporarily spatial scales are relative in nature and are developed as a social effort. There is an observable shift from the studies of hierarchised space (interactions in confined spaces of permanent dimensions) to sets of interaction networks between various places, with fluid boundaries. Scale, in the meaning of the dimension and level of phenomena and processes, is established by interactions (social relations between subjects) and not strictly a distance (Lisowski, 2009).

\section{WHITHER HUMAN GEOGRAPHY?}

In the early twenty-first century, the identity and functions of human geography are changing rapidly, in a number of directions. On the one hand, this is caused by the need to adapt to the external conditions in which the discipline operates, and on the other it is viewed as a compromise between traditions and challenges of the future. Among the latter, competition in the science marketplace is gaining in importance. Phenomena and processes of a given category and in given locations on the earth's surface are constantly fluctuating. The cognitive functions on the one hand involve the updating of facts and on the other they aim to verify regularities which are found in the natural and social science. Geographers fulfil their natural role when they identify change in the very place where it occurs, as well as its complexity. A more ambitious task is to verify theoretical concepts developed in the social sciences. It is not the unique nature of a given area that matters 
but the diagnosis of the relationships between structures and processes and the specific nature of the local conditions. Sciences have always borrowed from one another. Derivative position with respect to other sciences does not mean intellectual inferiority but necessary adjustment to enormous complexity of research problems (Harvey, 1969, 124).

Do geographical studies refer to the holistic approach to the problems, or just verify the correctness of the economic, social or political rules due to the impact of the real constraints and influences of regional and local level? These questions are valid in the context of geographical critique of the World Development Report 2009, prepared exclusively by economists. That criticism echoes the idea of geography as a synthesizing science, since according to geographic reviewers the Report omits social and environmental determinants of development, over-simplifies political, institutional, and cultural issues, as well as eliminates history (Rigg et al., 2009). The Report is also affected by neoliberal ideology (Harvey, 2009; Scott, 2009). However, in a sea of critical arguments, the reviewers do not give credit to attempt of conceptualization of spatial development, as universal component of knowledge. In the opinion of geographers the economics aims towards the homogenisation of the economic realm through universalism, application of the homo oeconomicus model and an excessive belief in the efficiency of market mechanisms, a stance which economic geography diligently tries to avoid (Coe et al., 2007, 10).

More far-reaching changes can be observed in relation to the practical function. The weakening of the traditional cultural and information function responsible for the development of geographical self-awareness among the general public has been a painful experience for geographers. A half century ago a geographer, who was described by Antoine Saint Exupéry, had estimated the usefulness of whole knowledge about earth's surface for wide bunch of recipient, but now the modern geographer is substituted by representatives of other social disciplines and aggressive media. On the other hand, commercialisation of science has strengthened the role of the technical function, associated with the broadly understood local and regional development, a trend which has brought geography closer to the two applied sciences: spatial management and spatial planning, which more or less intercept the achievements of geography. In the short term, this direction of change seems rather attractive in view of the current criteria of funding science, but the long term effects may prove undesirable because the perception of geography as a consumer and not producer of knowledge will be consolidated. Specialisation in the preparation of research projects, with a view to providing additional funding for science, may promote scholars who are extremely able organisationally but not necessarily intellectually creative (Domański, 2006).

In reality, spatial studies still remain at the periphery of research in other social sciences. The dissimilar traditions of individual disciplines emphasise their complementary nature, although examples of cooperation also go together with instances of rivalry. It would probably be desirable in human geography to curb the thematic diversity by defining research priorities. The 
constant visiting and revisiting of the local varia without mainstream of research may be concordant with the stereotyped view of geographers as explorers, but it cannot justify the waning interest in the discipline's universalistic component in an era of strong competition in science.

Consolidation of social sciences within individual disciplines in the last decades has been diminishing, but the conviction of unified social science seems still to be premature. The growing proximity of economics and psychology is still accompanied by a gap between economics and sociology (Czwarno, 2003). The contemporary socio-cultural turn in human geography means a shift from the idea of homo oeconomicus to homo sociologicus (as "oversocialized" subject). That change contains a movement from a decision-making approach (close to behavioural economics, psychology and to some extend evolutionary biology) to systemic approach (taking into account diversity of preconditions of human behaviour affected by social structure), from individual interest to social values, and finally from micro-rationality to macro-rationality (Lopreato and Crippen, 1999, 20-21; Czwarno, 2003, 120121). To a large extent, this means a movement of geography away from the classic model of analytical science and reminds a turn towards discipline, which synthesizes the spatial and social realities.

\section{REFERENCES}

Ackerman E.A. 1963, Where is a research frontier? Annals of the Association of American Geographers, 53 (4), 429-440.

Andersson R., Musterd S., 2003, Area-based policies: a critical appraisal, Tijdschrift voor Economische en Sociale Geografie, 96, 4, s. 377-389.

Aoyma Y., Murphy J.T., Hanson S., 2011, Key Concepts in Economic Geography, Sage, London. Bingham N., Thrift N., 2000. Some new instructions for travelers: the geography of Bruno

Latour and Michel Serres. [in:] Crang M., Thrift N. (ed.) Thinking Space. Routledge, LondonNew York, 281-301.

Blaut J.M., 1962. Object and relationship, Professional Geographer, 14, 1-6.

Bourdieu P. 1975, The specificity of the scientific field and the social conditions of the progress of reason, Social Science Information, 14 (6), 31-47.

Bridge G., Watson S., 2000, City Imaginaries [in:]. (ed.) A companion of the city, Blackwell Publishing, Malden-Oxford 7-18, 7-17.

Brigham A.P., 1915, Problems of geographic influence, Annals of the Association of American Geographers, 5, 3-25.

Brown E.H. 1975, The content and relationships of physical geography, The Geographical Journal, 141, 1, 35-40.

Brzeziński M., Gorynia M., Hockuba Z., 2008, Ekonomia a inne nauki społeczne na początku XXI wieku, Między imperializmem a kooperacja [Economics and other social sciences at the beginning of XXIst century. Between imperialism and cooperation], Ekonomista, 2, 201-232

Burt W. 2005, General / particular, [in:] Castries N., Rogers A., Sherman D., (eds.) Questioning Geography. Fundamental Debates, Blackwell Publishing, Malden-Oxford, 117-130.

Castells M., 1977, Urban Question, A Marxist Approach, E. Arnold, London.

Castree N., 2005, Is geography a science? [in:] Castries N., Rogers A., Sherman D., (eds.) Questioning Geography. Fundamental Debates, Blackwell Publishing, Malden-Oxford, 57-79. 
Chojnicki Z., 2004, Problematyka metodologiczna studiów regionalnych [Metodological problems of regional studies], Studia Regionalne i Lokalne, 4 (18), 5-11

Chojnicki Z., 1996, Region w ujęciu geograficzno-systemowym [ Region in geographic-systemic approach] [in:] Czyż T. (ed.), Podstawy regionalizacji geograficznej, Bogucki Wyd. Naukowe, Poznań, 7-44.

Chojnicki Z., 1988, Basic philosophical and methodological problems of space and time, Concepts and Methods in Geography 3 (1988), 9-23).

Chojnicki Z., 1973, Założenia i perspektywy rozwoju geografii ekonomicznej [Assumptions and perspectives of of economic geography development], Przeglad Geograficzny, 45, 1, 3-27.

Coe N.M., Kelly P.F., Yeung H.W.C. 2007, Economic geography: a contemporary introduction, Blackwell Publishing, Malden.

Czwarno M., 2003, Homo oeconomicus kontra homo sociologicus, czyli dlaczego ekonomiści nie lubią socjologów, a socjologowie nie przepadają za ekonomistami, [Homo economicus vs. homo sociologicus, that is why economists do not like sociologists, and sociologists are not fond of economists] Studia Socjologiczne, 3 (170), 113-135.

David P.A. 2001, Path dependence, its critics and the quest for 'Historical Economics' [in:] Garrouste P., Ioannides S. (eds.) Evolution and Path Dependence in Economic Ideas; Past and Present, Edward Elgar Publishing, Cheltenham, 15-40.

Del Casino J.V. 2009, Social Geography: A Critical Introduction, Chichester, Wiley-Blackwell.

Dogan M., 1996, The hybridization of social science knowledge - Navigating among the disciplines: The library and interdisciplinary inquiry, Library Trends, 45, 2, 296-314.

Dogan M., Pahre R., 1989, Fragmentation and recombination of the social sciences, Studies in Comparative International Development, summer, 24, 2, 56-73.

Domański H., 2006, Niektóre zagrożenia profesjonalizacji [Some hazards of professionalisation] [in:] Polskie nauki humanistyczne $i$ spoteczne $w$ nowym stuleciu $w$ nowej Europie, Wydawnictwo Instytut Badań Literackich PAN, Warszawa, 46-51.

Dominiak Ł. M., 2006, Strategie interdyscyplinarności w perspektywie naukoznawczej [Strategies of interdisciplinarity in scientific perspective], [in:] Kowalewski J., Piasek W., Śliwa M. (eds.) Granice dyscyplinarne w humanistyce, Colloquia Humaniorium, Olsztyn, 47-60

Dybiec J., 1993, Polska Akademia Umiejętności 1872-1952 [ Polish Academy of Arts and Sciences 1872-1952] Secesja, Kraków.

Elster J., 2010, One social science or many? \{in:] World Social Science Report 2010, Knowledge Divides, UNESCO Publishing, International Social Science Council, Paris, 199-203.

Fenneman N.M., 1919, The circumference of geography, Annals of the Association of American Geographers, 9, 3-11.

Gibbons M., Limoges C., Nowotny H., Schwartzman S., Scott P., Trow M., 1994, The new production of knowledge. The dynamics of science and research in contemporary societies, Sage Publications, London.

Giddens A., 1991, Modernity and Self-Identity: Self and Society in the Late Modern Age, Polity Press, Blackwell Publishers, London.

Golledge R.G. Stimson R.J., 1997, Spatial Behavior: A Geographical Perspective, Guilford Press, New York- London.

Grobler A., 2006, Metodologia nauk [Methodology of science], Aureus-Znak, Kraków.

Hamnett C. 2003, Contemporary geography: fiddling while Rome burns, Geoforum 34, 1-3.

Hardt M., Negri A., 2000, Empire, Harvard University Press, Harvard.

Hartshorne R., 1959, Perspective on the nature of geography, AAAG/ Rand McNally, Chicago.

Harvey D., 2009, Reshaping economic geography: The World Development Report 2009, Development and Change 40, 6, 1269-1277.

Harvey D., 1969, Explanation in geography, Edward Arnold, London.

Isačenko A.G., 1975, Historia myśli geograficznej, [A history of geographical thought] PWN, Warszawa.

Jackowski A., Sołjan I., 2009, Z dziejów geografii na Uniwersytecie Jagiellońskim (XV-XXI wiek) [The history of geography at Jagiellonian University (XV-XXI century)], Uniwersytet Jagielloński, Kraków. 
Jahn A., 1990, Podsumowanie i komentarz [Czym była i jest polska geografia] [What was and is Polish geography], Czasopismo Geograficzne 3-4, 180-186.

James P.E., Martin G.J., 1981, All possible worlds. A history of geographical ideas, J. J. Wiley and Sons, New York.

Johnston R., 2003, Geography: a different sort of discipline? "Transactions, Institute of British Geographers NS", 28, 133-141.

Johnston R. 2002, Reflection on Nigel Thrift's optimism: political strategies to implement his vision, Geoforum 33, 421-425.

Johnston R.J., 1997, Geography and geographers; Anglo-American human geography since 1945, Blackwell, London-New York-Sydney-Auckland.

Kamiński S. 1981, Pojęcie nauki i klasyfikacja nauk, [The concept of science and classification of sciences], Rozprawy Wydziału Filozoficznego. Towarzystwo Naukowe Katolickiego Uniwersytetu Lubelskiego, Lublin.

Kitchen R., Blades M., 2001, The cognition of geographic space, I.B. Tauris, London.

Kuijper H., 2008, Area Studies versus Disciplines: Towards an Interdisplinary, Systemic Country Approach, The International Journal of Interdisciplinarity Social Sciences, 3, 7, 205-216.

Laponce J.A., 1980, Political Science: An Import-Export Analysis of Journals and Footnotes, Political Studies, 401-419.

Lefebvre H., 1991, The production of space, Blackwell, Oxford-Cambridge MA.

Lopreato J., Crippen T., 1999, Crisis in Sociology; The Need for Darwin, Transaction Publishers, New Brunswick NJ.

Kaltenberg-Kwiatkowska E., 2007, Socjologia przestrzeni w Polsce. Narodziny subdyscypliny [Sociology of space in Poland. Birth of a subdiscipline] [in:] Borowik I., Sztalta K., (eds.) Wspótczesna socjologia miasta. Wielość ogladów i kierunków badawczych, Wyd. Uniwersytetu Wrocławskiego, Wrocław, 9-24.

Kates R.W., 2002, Humboldt's dream, beyond disciplines, and sustainability science: contested identities in restructuring Academy, Annals of the Association of American Geographers, $92(1), 79-81$.

Kaufmann A., Kasztler A., 2009, Differences in publication and dessemination practices between disciplinary and transdisciplinary science and the consequences for research evaluation, Science and Public Policy, 36 93), April, 215-227.

Kotarbiński T., 1961. Elementy teorii poznania, logiki formalnej i metodologii nauk, [ Elements of the theory of knowledge, formal logic and methodology of science], Ossolineum, Wrocław.

Krajewski W., 1982. Prawa nauki. Przeglad zagadnien metodologicznych i filozoficznych [The laws of science. Review of methodological and philosophical issues], PWN, Warszawa.

Kula M. 2010, Przyszłość historyków [The future of historians], Uniwersytet Warszawski 5(49), 12-13.

Lisowski A., 2009, Jakie „studia regionalne” moga podnieść prestiż geografii [What regional studies can raise the prestige of geography?], [in:] Richling A., Lechowicz M., (eds.) Studia regionalne a rozwój geografii, KNG PAN, WGSR UW, Warszawa, 23-38.

Lisowski A., 2006, Przedmiot badań, funkcje i tożsamość geografii na początku XXI wieku [The subject of research, functions and identity of geography at the beginning of the twentyfirst century] [in:] Maik W., Rembowska K., Suliborski A. (eds.) Geografia a przemiany wspótczesnego świata; Podstawowe idee i koncepcje w geografii T. 3, Wyższa Szkoła Gospodarki, Bydgoszcz 2007, 39-54.

Lisowski A. 2004, Geografia społeczno-ekonomiczna a nauki społeczne [Socio-economic geography and social sciences] [in:] Chojnicki Z. (ed.) Geografia wobec problemów teraźniejszości i przyszłości, Bogucki Wydawnictwo Naukowe, Poznań, 2004, 67-80.

Lisowski A., 2003, Koncepcje przestrzeni w geografii czlowieka, [The concepts of space in human geography], WGSR Uniwersytet Warszawski, Warszawa.

Lisowski A., 1996. Tendencje dezintegracyjne i integracyjne we współczesnej geografii człowieka [Disintegrative and integrative tendencies in contemporary human geography]Przeglad Geograficzny 68, 3-4, 317-333.

Maik W., 2004, Główne płaszczyzny relacji między geografią fizyczną a geografią społecznoekonomiczna [The main planes of the relationships between physical geography and socio- 
economic geography [in:] Chojnicki Z. (ed.) Geografia wobec problemów teraźniejszości i przyszłości, Bogucki Wydawnictwo Naukowe, Poznań, 2004, 9-24.

Martin R., 1999, The new 'geographical turn' in economics: some critical reflections, Cambridge Journal of Economics, 23, 65-91.

Melezin A., 1985, Wiktor Ormicki w Wilnie [Wiktor Ormicki in Vilnius] Czasopismo Geograficzne, $55,3-4,433-434$.

Morillo F., Bordons M., Gomez I. 2003, Interdisciplinarity in Science: A Tentative Typology of Disciplines and Reserch Areas, Journal of the American Society for Information Science and Technology, 54 (13) 1237-1249.

Mulligan G.F., 2003, What's wrong with economic geography ? Other thoughts on the rift, Canadian Journal of Regional Science, XVI, 1, 33-37.

Nowakowski S. 1934-35, Geografja jako nauka i dzieje odkryć geograficznych, [Geography as a science and history of geographical discoveries] Wielka Geografia Powszechna, T.1. Trzaska, Evert i Michalski, Warszawa.

Passen van C., 1957, The classical tradition of geography, JB Wolters, Groningen.

Ratajczak M., 2009, Economics in the Age of Crisis: between Anti-Economics and Economic Triumphalism, [in:] Kopycińska D. (ed.), Decision Makers'Behaviour under the Conditions of Crisis Threat, University of Sczecin, Microeconomics Department, Szczecin, 22- 31.

Rigg J., Bebbington A., Gough K.V., Bryceson D.F., Agergaard J., Fold N., Tacoli C., 2009, The World Development Report 2009 'reshapes economic geography': geographical reflections, Transactions, Institute of British Geographers NS, 34, 128-136.

Sawicki L. 1932, Zarys ogólnej geografiji ziem polskich, [An outline of the overall geography of the Polish lands], Kraków.

Scott A., 2009, World Development Report 2009; reshaping economic geography, Journal of Economic Geography, 9, 583-586.

Smith N., 1987, "Academic war over the field of geography": the elimination of geography at Harvard, 1947-1951, Annals of the Association of American Geographers, 77 (2) 155-172.

Soja E. W., 1989. Postmodern geographies: the reassertion of space in critical social theory, Verso, London

Such 1987, Klasyfikacja nauki [Classification of science] [in:] Cackowski Z., Kmita J., Szaniawski K., Smoczyński P.J. (eds) Filozofia nauki, PWN, Warszawa, 297-305.

Such J., Szcześniak M., 1999, Filozofia nauki, [Philosophy of science]. Wyd. UAM, Poznań.

Sztompka P., 2002, Socjologia. Analiza spoteczeństwa, [Sociology. Analysis of society], Znak, Kraków.

Tatarkiewicz W., 1945, Nauki nomologiczne i typologiczne [Nomothetic science, and typological] Sprawozdania PAU, t 46, nr 15.

Thrift N. 2002, The future of geography, Geoforum 33, 291-298.

Turner B.L. II, 2002, Contested Identities: Human environment geography and disciplinary implications in a restructuring Academy, Annals of the Association of American Geographers, 91, (1) 52-74.

Valentine G. 2000, Social geographies. Space \& Society, Pearson Education Ltd, Harlow.

Viles H., 2005, A divide discipline? [in:] Castries N., Rogers A., Sherman D., (eds.) Questioning Geography. Fundamental Debates, Blackwell Publishing, Malden-Oxford, 26-38.

Wagner H., 1880, Bericht über die Entwicklung der Methodik der Geographie als Wissenschaft, Geographisches Jahrbuch, 8, 523-598.

Wallerstein I. 1996, Open the social sciences: Report of the Gulbenkian Commision on the Restructuring of the Social Sciences, Stanford.

Wallis A., 1971, Socjologia i kształtowanie przestrzeni, [Sociology and shaping of space], PIW, Warszawa.

Werlen B., 1993, Society, action and space. Routledge, London-New York.

World Social Science Report 2010, Knowledge Divides, UNESCO Publishing, International Social Science Council, Paris.

Zaborski B., Wrzosek A. 1939, Antropogeografia [Anthropogeography], Trzaska, Evert, Michalski, Warszawa. 